\title{
Detecção de Histophilus somni (Haemophilus somnus) no sêmen bovino mediante reação em cadeia pela polimerase (PCR)
}

\author{
Detection of Histophilus somni (Haemophilus somnus) in \\ bovine semen using polymerase chain reaction (PCR)
}

Francisca Elda Ferreira Dias ${ }^{[a]}$, Cáris Maroni Nunes ${ }^{[b]}$, Tânia Vasconcelos Cavalcante ${ }^{[c]}$, Juliano Franco de Souza[ ${ }^{[d]}$, Silvia Minharro Barbosa ${ }^{[e]}$, Andréa Azevedo Pires de Castro ${ }^{[f]}$, Felipe de Jesus Moraes Jr. ${ }^{[g]}$, Claúdia Marinovic Oliveira ${ }^{[h]}$, José Fernando Garcia ${ }^{[i]}$

[a] Médica veterinária, doutora em Medicina Veterinária, professora da Escola de Medicina Veterinária e Zootecnia da Universidade Federal de Tocantins (UFT), Araguaína, T0 - Brasil, e-mail: eldadias@uft.edu.br

[b] Médica veterinária, doutora em Epidemiologia Experimental, professora do Departamento de Medicina Veterinária, Laboratório de Bioquímica e Biologia Molecular Animal da Universidade Estadual Paulista "Júlio de Mesquita Filho" (Unesp), Araçatuba, SP - Brasil, e-mail: caris@fmva.unesp.br

[c] Médica veterinária, doutora em Medicina Veterinária, professora do Departamento de Clínica e Cirurgia Veterinária da Universidade Federal do Piauí (UFPI), Teresina, PI - Brasil, e-mail: cavalcante.tv@gmail.com

[d] Médico veterinário, mestre em Medicina Veterinária, Universidade Estadual Paulista "Júlio de Mesquita Filho" (Unesp), Jaboticabal,SP-Brasil, e-mail: julianofranco@uol.com.br

[e] Médica veterinária, doutora em Ciência Animal, professora da Escola de Medicina Veterinária e Zootecnia da Universidade Federal de Tocantins (UFT), Araguaína, T0 - Brasil, e-mail: silviaminharro@yahoo.com.br

[f] Médica veterinária, mestre em Clínica Médica, coordenadora de Pesquisa Clínica na Fundação de Medicina Tropical do Tocantins (Funtrop), Araguaína, T0 - Brasil, e-mail: andrearaguaina@hotmail.com

[g] Médico veterinário, doutor em Reprodução Animal, professor adjunto da Universidade Estadual Paulista "Júlio de Mesquita Filho" (Unesp), Araçatuba, SP - Brasil, e-mail: fmoraesjr@hotmail.com

[h] Médica veterinária, doutora em Ciências, professora da Faculdade de Ensino Superior da Amazônia Reunida (Fesar), Redenção, PA - Brasil, e-mail: claumarinovic@hotmail.com

[i] Médico veterinário, doutor em Reprodução Animal, professor do Departamento de Medicina Veterinária, Laboratório de Bioquímica e Biologia Molecular Animal da Universidade Estadual Paulista “Júlio de Mesquita Filho" (UNESP), Araçatuba, SP - Brasil, e-mail: jfgarcia@fmva.unesp.br

\section{Resumo}

O presente estudo avaliou o uso da PCR para a detecção do Histophilus somni no sêmen bovino. Amostras de sêmen foram contaminadas experimentalmente com $H$. somni diluída em escalas de $10^{7}$ a $10^{1}$ bactérias / $\mathrm{mL}$, submetidas à extração de DNA pelo método de fenol/clorofórmio e amplificadas pela PCR. Os produtos da amplificação do DNA foram analisados por eletroforese em gel de acrilamida 8\%. Por meio de oligonucleotídeos iniciadores obteve-se a amplificação de um fragmento de 400 pares de bases a partir do DNA da bactéria. Conseguiu-se amplificação positiva até na diluição de $10^{1}$ bactérias $/ \mathrm{mL}$. A PCR mostrou-se eficiente na detecção de H. somni. 0 resultado disponibiliza conhecimento relevante para o diagnóstico de H. somni, 
justificando a necessidade do diagnóstico dessa bactéria em reprodutores, especialmente em amostras de sêmen, que deveriam estar livres de qualquer contaminação. A PCR mostrou-se como uma valiosa ferramenta no controle da qualidade do sêmen produzido em centrais de inseminação artificial.

Palavras-chave: Bovino. Sêmen. Histophilus somni. PCR.

\begin{abstract}
The present study evaluated the use of PCR for Histophilus somni detection in bovine semen. Semen samples were experimentally infected with $\mathrm{H}$. somni at dilutions ranging from 107 to 101 bacteria/mL and subjected to DNA extraction by the phenol/chloroform method, followed by PCR amplification. The amplification products were analyzed by electrophoresis in $8 \%$ acrylamide gel. The oligonucleotide primers used yielded an amplification fragment of 400 base pairs from the bacterial DNA. Positive amplification was obtained even for the 101 bacteria/mL dilution. PCR proved to be an efficient method for the detection of H. somni. The results obtained in this study have brought relevant information for the diagnosis of H. somni, justifying the need for the diagnosis of this bacterium in bulls, especially in semen samples that should be free of contamination. The PCR method has shown to be a useful tool for the quality control of semen produced in artificial insemination centers.
\end{abstract}

Keywords: Cattle. Semen. Histophilus somni. PCR.

\section{Introdução}

Histophilus somni (Haemophilus somnus) é uma importante bactéria que pode desencadear quatro diferentes tipos de manifestações clínicas: doença respiratória, meningoencefalopatia trombótica (TEM), artrite e distúrbios reprodutivos, além de otite, conjuntivite, cegueira, mastite e septicemia (WARD et al., 2006).

Na fêmea se observam descargas vulvares, metrite, vulvovaginite granular, infertilidade por morte embrionária precoce, abortamento por morte fetal e placentite ao redor de 6-9 meses de gestação, podendo ocorrer retenção de placenta; enquanto no macho ocorre balanopostite e sêmen mucopurulento. Por outro lado, pode ser isolada do trato urogenital de até $90 \%$ de machos e $28 \%$ de fêmeas sadias, comportando-se como microrganismo comensal (SCARCELLI et al., 2004).

A identificação dessa bactéria é difícil, uma vez que exibe extensa variabilidade morfológica e bioquímica. 0 diagnóstico do agente pode ser realizado por meio de cultivo e análise morfológica do patógeno (FERRERAS et al., 2007).

Nos últimos anos, a técnica de reação em cadeia pela polimerase (PCR) vem sendo realizada com sucesso na detecção de vários agentes infecciosos em amostras de sêmen. Gerber et al. (2010) utilizaram a PCR para a detecção de vírus, Mukhufhi et al. (2003) para detecção de protozoários e Saunders et al. (2007) utilizaram a técnica de reação em cadeia da polimerase múltipla (mPCR) para obter a padronização da detecção simultânea de Brucella ovis, Actinobacillus seminis e H. somni em sêmen fresco de ovinos.

Entretanto, ainda são poucas as pesquisas para detecção de agentes infecciosos de transmissão venérea em amostras de sêmen. Assim, pesquisas visando à detecção de agentes bacterianos no sêmen bovino por PCR vêm sendo intensificadas a cada ano (MAGAJEVSKI; GÍRIO, 2008; SAUNDERS et al., 2007).

A PCR pode acrescentar vantagens aos métodos rotineiros de diagnóstico de infecções bacterianas no sêmen. 0 objetivo deste estudo foi avaliar o uso da PCR na detecção de H. somni em sêmen bovino.

\section{Material e métodos}

0 estudo foi realizado no Laboratório de Bioquímica e Biologia Molecular Animal da Unesp, 
Campus Araçatuba. Foram analisadas amostras de sêmen bovino livres do patógeno, oriundas de touro mantido em regime de coleta semanal, sob rigoroso controle sanitário. Procedeu-se à extração do DNA do sêmen antes da contaminação experimental e realizou-se a amplificação do DNA utilizando os oligonucleotídeos específicos de H. somni.

A cepa padrão da bactéria Haemophilus somnus foi adquirida na American Type Culture Collection (ATCC no 700025). Para estimar a concentração de bactérias, realizou-se a diluição da solução estoque em solução salina fisiológica e utilizou-se a escala de McFarland (escala 0,5), chegando ao resultado de 1,5x $10^{5}$ bactérias/mL. Essa solução foi empregada para a contaminação experimental das amostras de sêmen.

Para determinar a menor concentração de DNA bacteriano através da PCR, após descongelação o sêmen foi diluído em solução salina $0,9 \%$ para uma concentração de $30 \times 10^{6}$ espermatozóides $/ \mathrm{mL}$ determinada através de contagem em câmara de Neubauer, a qual se denominou "dose inseminante". As amostras foram contaminadas com concentrações decrescentes de H. somni obtidas por diluições seriadas na base 10 , de modo a resultar em amostras contendo de $10^{7}$ a $10^{1}$ bactérias $/ \mathrm{mL}$. Em seguida, foi realizada a extração de DNA segundo protocolo descrito por Dias (2005).

Os ensaios de PCR foram realizados em microtubos de $200 \mu \mathrm{L}$, com volume total de $25 \mu \mathrm{L}$ contendo: $200 \mathrm{mM}$ de Tris- $\mathrm{HCl} \mathrm{pH}$ 8,4 (InvitrogenLife Technologies ${ }^{\circledR}$ CA, EUA), 2,5 mM de cloreto de magnésio (Invitrogen-Life Technologies ${ }^{\circledR}$ CA, EUA), 1,25 mM de cada desoxiribonucleotídeo trifosfatado-dNTP (Invitrogen-Life Technologies ${ }^{\circledR}$, CA, EUA), 10 pmol de cada oligonucleotídeo iniciador, 1 Unidade de Taq DNA Polimerase (InvitrogenLife Technologies ${ }^{\circledR}$ - Brasil) e água ultra pura (Invitrogen-Life Technologies ${ }^{\circledR}$ CA, EUA) q.s.p. 25 $\mu \mathrm{L}$, além de $5 \mu \mathrm{L}$ de amostra de DNA. Controles negativos contendo todos os reagentes exceto DNA foram incluídos para monitoramento de possíveis contaminações, bem como controles positivos com DNA purificado de cultura bacteriana específica.

As amostras foram amplificadas por PCR em termociclador de temperatura programável (PTC$100^{\mathrm{TM}}$ Programmable Thermal Controler, MJResearch ${ }^{\circledR}$, CA, EUA), utilizando-se oligonucleotídeos iniciadores HF-5'GAAGGCGATTAGTTTAAGAG3' e
HR-5'TTCGGGCACCAAGTRTTCA'3 descritos na literatura, que amplificam a região do gene 16S rRNA que amplifica um fragmento de 400 pares de base (ANGEN; AHRENS; TEGTMEIER, 1998). Os microtubos contendo o DNA foram submetidos a 35 ciclos de amplificação, precedidos por desnaturação inicial a $94{ }^{\circ} \mathrm{C}$ por 5 minutos. Os ciclos consistiram de desnaturação a $94{ }^{\circ} \mathrm{C}$ por 60 segundos, hibridização dos oligonucleotídeos iniciadores a $55 \stackrel{\circ}{\circ}$ por 60 segundos e extensão a $72{ }^{\circ} \mathrm{C}$ por 60 segundos. Ao final de 35 ciclos, os tubos foram mantidos a $72{ }^{\circ} \mathrm{C}$ por 10 minutos.

Os produtos da amplificação do DNA foram separados por eletroforese em gel de acrilamida 8\% corado com nitrato de prata, analisados sobre luz branca e fotografados com aparelho de fotodocumentação (Kodak ${ }^{\circledR}$ Electrophoresis Documentation and Analysis System 120, Rochester, NY, EUA).

\section{Resultado e discussão}

Dentre os diversos patógenos que afetam a bovinocultura, listados pela Organização Mundial de Saúde Animal (World Organization For Animal Health - OIE) (THIBIER; GUERIN, 2000), alguns têm papel de relevante importância na situação brasileira como, por exemplo, a Brucella abortus (POESTER; GONÇALVES; LAGE, 2002), a Leptospira sp. (HEINEMANN et al., 2000) e o Campylobacter fetus (VARGAS et al., 2003). Outro patógeno da lista $B$ da OIE que apresenta significância econômica em outros países mas ainda não foi devidamente estudado no Brasil é o H. somni (TEGTMEIER; ANGEN; AHRENS, 2000).

Após extração do DNA e realização da PCR utilizando-se oligonucleotídeos específicos, obteve-se a amplificação de fragmentos com 400pb do DNA bacteriano no tamanho esperado em todas as amostras. Na análise do limiar de detecção observou-se resultados de amplificação positiva até diluições de $10^{1}$ bactérias/mL (Figura 1 ).

A técnica da PCR foi objeto de estudo para a detecção de diversos agentes infecciosos no sêmen bovino, tais como o Campylobacter fetus (EAGLESOME; SAMPATH; GARCIA, 1995), Leptospira spp. (HEINEMANN et al., 1999; 2000), Brucella melitensis (AMIN; HAMDY; IBRAHIM, 2001) e Neospora caninum (ORTEGA-MORA et al., 2003). No sêmen de 


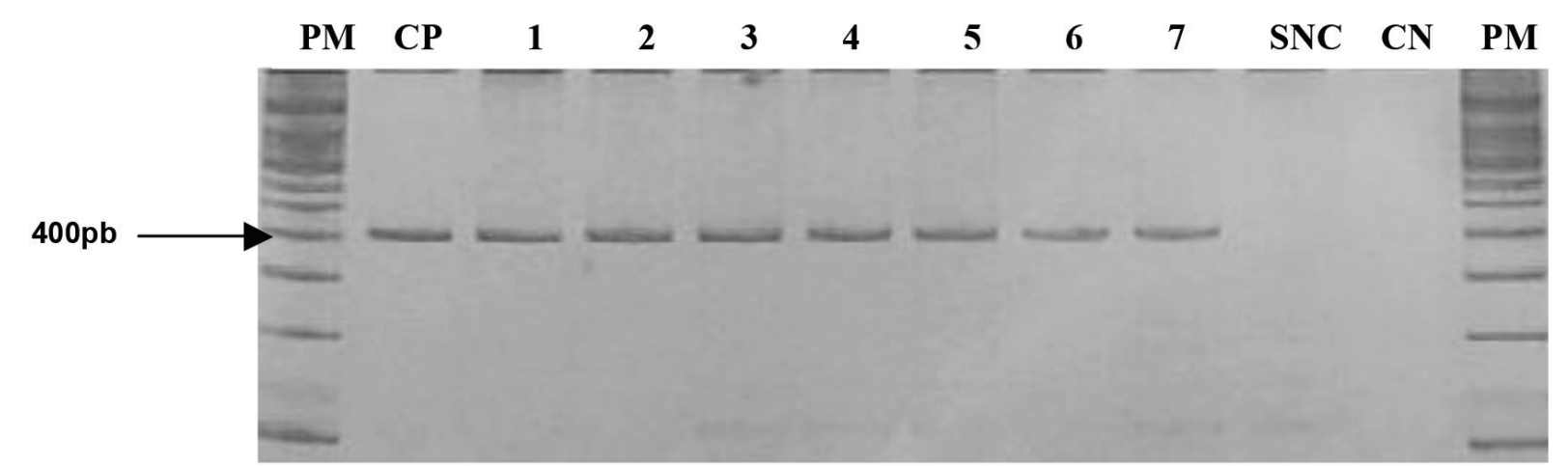

Figura 1 - Eletroforese em gel de poliacrilamida 8\% corado com nitrato de prata. Produtos de amplificação por PCR do DNA de amostras de sêmen contaminadas experimentalmente com Histophilus somni (Haemophilus somnus) mostrando o limiar de detecção.

Legenda: PM - marcador de peso molecular em escada de 100pb; CP - controle positivo de Histophilus somni; linhas 1 a 7 - diluição seriada na base $10\left(10^{7}\right.$ a $10^{1}$ bactérias/mL); SNC - sêmen não contaminado; CN - controle negativo (sem DNA).

Fonte: Dados da pesquisa.

outras espécies, a PCR foi usada em pesquisas recentes na detecção de vírus em javali (GERBER et al., 2010), Toxoplasma gondii no carneiro (MORAES et al., 2010) e bactérias em ovinos (SAUNDERS et al., 2007).

Entretanto, ainda são poucos os estudos realizados no Brasil com objetivo de detectar H. somni no sêmen bovino e essa bactéria nem mesmo consta na lista dos agentes oficialmente reconhecidos pelo Ministério da Agricultura, Pecuária e Abastecimento (MAPA) em provas sorológicas exigidas para atestar a qualidade sanitária do sêmen em centrais de inseminação artificial.

Dias (2005) padronizou com sucesso um multiplex PCR fluorescente para detecção simultânea de Brucella spp., Leptospira spp., Haemophilus somnus e Campylobacter spp. no sêmen bovino. Para testar a eficiência do multiplex PCR fluorescente padronizado, no estudo foram avaliadas 22 amostras de sêmen adquiridas no mercado nacional, e detectou-se o H. somni em 18 dos 22 (81,81\%) touros testados.

Segundo Harris e Janzen (1989), o aparelho urogenital pode ser considerado o nicho ecológico ou reservatório de H. somni em touros. Essa bactéria é comumente isolada a partir do prepúcio, embora também possa ser recuperada a partir da bexiga, glândulas sexuais acessórias e ampolas. Afirmam ainda que, com exceção de relatos frequentes de infertilidade e qualidade do sêmen, o microorganismo parece não causar lesões nesses locais; no entanto, pode contaminar o sêmen, e este pode constituir-se em um mecanismo de difusão.

Os métodos tradicionais usados na identificação de animais portadores de agentes infecciosos são: isolamento em meio de cultivo, cultivo celular, soroneutralização, teste de fixação de complemento, ELISA, imunofluorescência indireta, hemaglutinação e imunodifusão. A maioria dessas técnicas apresenta limitações de ordem prática resultantes da complexidade, lentidão dos procedimentos para detectar e caracterizar o agente infeccioso ou ainda infraestrutura laboratorial necessária, além das limitações relativas à sensibilidade e especificidade, que são fatores complicadores para a realização de diagnóstico de baixo custo, prático e preciso (CICERONI et al., 2002; MANTEROLA et al., 2003). Assim, torna-se necessário a busca por métodos que apresentem mais especificidade, sensibilidade e rapidez no diagnóstico de bactérias no sêmen de touros a campo e de central de inseminação.

A disseminação de $H$. somni no sêmen, urina ou secreções genitais em acasalamento natural é uma possibilidade. 0 significado epidemiológico de disseminação do organismo a partir do trato urogenital e a avaliação da eficácia de antibióticos na supressão do organismo de sêmen processado para inseminação artificial são também dignos de investigação (HUMPHREY et al., 1982). Os dados da literatura (DIAS, 2005; SAUNDERS et al., 2007) mostram que essa bactéria é um patógeno sexualmente transmissível e reforçam a necessidade de mais estudos sobre a possível ocorrência de transmissão 
venérea através do sêmen e secreções prepuciais de bovinos utilizados como reprodutores em propriedades rurais e nas centrais de inseminação.

0 risco potencial de transmissão venérea de bactérias através do sêmen provoca grande preocupação acerca do intercâmbio nacional e internacional de material genético, especialmente com a escolha de métodos de diagnóstico adequados para a certificação de sua qualidade, obrigando quase todos os países a implantarem programas sanitários rigorosos no controle das exportações.

\section{Conclusão}

A PCR mostrou-se método eficiente na detecção de H. somni. 0 resultado obtido trouxe conhecimentos relevantes para o diagnóstico de H. Somni no sêmen bovino, constituindo-se em valiosa ferramenta no controle da qualidade do sêmen.

\section{Referências}

AMIN, A. S.; HAMDY, M. E. R.; IBRAHIM, A. K. Detection of Brucella melitensis in semen using the polymerase chain reaction assay. Veterinary Microbiology, v. 83, n. 1, p. 37-44, 2001. doi:10.1016/S0378-1135(01)00401-1.

ANGEN, O.; AHRENS, P.; TEGTMEIER, C. Development of a PCR test for identification of Haemophilus somnus in pure and mixed cultures. Veterinary Microbiology, v. 63, n. 1, p. 39-48, 1998. PMid:9810620.

CICERONI, L. et al. Differentiation of leptospires of the serogroup pomona by monoclonal antibodies, pulsed-field gel eletrophoresis and arbritrarily primed polymerase chain reaction. Research in Microbiology, v. 153, n. 1, p. 37-44, 2002. doi:10.1016/S0923-2508(01)01284-0.

DIAS, F. E. F. Detecção de patógenos no sêmen bovino pela técnica de Multiplex PCR fluorescente. 2005. $59 \mathrm{f}$. Tese (Doutorado em Medicina Veterinária) - Faculdade de Ciências Agrárias e Veterinárias, Universidade Estadual Paulista "Júlio Mesquita”, Jaboticabal, 2005.

EAGLESOME, M. D.; SAMPATH, M. I.; GARCIA, M. M. A detection assay for Campylobacter fetus in bovine semen by restriction analysis of PCR amplified DNA. Veterinary Research Communications, v. 19, n. 4, p. 253-263, 1995. PMid:8540237.
FERRERAS, M. C. et al. Unilateral orchitis and epididymitis caused by Salmonella entérica subspecies diarizonae infection in a ram. Journal of Veterinary Diagnostic Investigation, v. 19, n. 2, p. 194-197, 2007. PMid:17402617.

GERBER, P. F. et al. Detection and dynamics of porcine circovirus 2 shedding in semen using conventional and real-time PCR. Pesquisa Veterinária Brasileira, v. 30, n. 11, p. 918-920, 2010. doi:10.1590/ S0100-736X2010001100004.

HARRIS, F. W.; JANZEN, E. D. The Haemophilus somnus disease complex (Hemophilosis): a review. The Canadian Veterinary Journal, v. 30, n. 10, p. 816-822, 1989. PMid:17423440.

HEINEMANN, M. B. et al. Detection and differentiation of Leptospira spp serovars in bovine semen by polymerase chain reaction and restriction fragment length polymorphism. Veterinary Microbiology, v. 73, n. 4, p. 261-267, 2000. doi:10.1016/S0378-1135(00)00150-4.

HEINEMANN, M. B. et al. Detection of leptospires in bovine semen by polymerase chain reaction. Australian Veterinary Journal, v. 77, n. 1, p. 32-34, 1999. PMid:10028391.

HUMPHREY, J. D. et al. Occurrence of "Haemophilus somnus" in bovine semen and in the prepuce of bulls and steers. Canadian Journal of Comparative Medicine, v. 46, n. 2, p. 215-217, 1982. PMid:7093816.

MAGAJEVSKI, F. S.; GÍRIO, R. J. S. Avaliação da sensibilidade da pcr frente a quatro técnicas para extração de DNA de Leptospira interrogans sorovar pomona em sêmen bovino experimentalmente contaminado. Ars Veterinária, v. 24, n. 1, p. 29-33, 2008.

MANTEROLA, L. et al. Evaluation of a PCR test for the diagnosis of Brucella ovis infection in semen samples from rams. Veterinary Microbiology, v. 92, n. 1-2, p. 65-72, 2003. PMid:12488071.

MORAES, E. P. B. X. et al. Detecção de Toxoplasma gondii no sêmen de ovinos naturalmente infectados. Pesquisa Veterinária Brasileira, v. 30, n. 11, p. 915-917, 2010. doi:10.1590/S0100-736X2010001100003.

MUKHUFHI, N. et al. Evaluation of a PCR test for the diagnosis of Tritrichomonas foetus infection in bulls: effects of sample collection methods, storage and transport medium on the test. Theriogenology, v. 60, n. 7, p. 1269-1278, 2003. doi: 10.1016/S0093-691X(03)00138-9. 
ORTEGA-MORA, L. M. et al. Detection of Neospora caninum in semen of bulls. Veterinary Parasitology, v.117, n.4, p. 301-308, 2003. PMid:14637032.

POESTER, F. P.; GONÇALVES, V. S. P.; LAGE, A. P. Brucellosis in Brazil. Veterinary Microbiology, v. 90, n. 1-4, p. 55-62, 2002. doi:10.1016/S0378-1135(02)00245-6.

SAUNDERS, V. F. et al. Multiplex PCR for the detection of Brucella ovis, Actinobacillus seminis and Histophilus somni in ram semen. Australian Veterinary Journal, v. 85, n. 5, p. 193, 2007. PMid:17300467.

SCARCELLI, E. et al. Abortion and embryonic death in bovine recipients due to Histophilus somni (Haemophilus somnus). Acta Scientiae Veterinariae, v. 32, n. 1, p. 59-64, 2004. TEGTMEIER, C.; ANGEN, Ø.; AHRENS, P. Comparison of bacterial cultivation, PCR, in situ hybridization and immunohistochemisty as tool for diagnosis of Haemophilus somnus in peneumoniain cattle. Veterinary Microbiology, v. 76, n. 4, p. 385-394, 2000. doi:10.1016/ S0378-1135(00)00259-5
THIBIER, M.; GUERIN, B. Hygienic aspects of storage and use of semen for artificial insemination. Animal Reproduction Science, v. 62, n. 1-3, p. 233-251, 2000. PMid:10924827.

VARGAS, A. C. et al. Phenotypic and molecular characterization of bovine Campylobacter fetus strains isolated in Brazil. Veterinary Microbiology, v. 93, n. 2, p. 121-132, 2003. doi:10.1016/S0378-1135(03)00018-X.

WARD, A. C. S. et al. Haemophilus somnus (Histophilus somni) in bighorn sheep. Canadian Journal of Veterinary Research, v. 70, n. 1, p. 34-42, 2006. PMid:16548330.

Recebido: 27/02/2013 Received: 02/27/2013

Aprovado: 19/07/2013 Approved: 07/19/2013 